\title{
Hydrological modeling of hydrographic basin in the northeast semiarid region of
}

\section{Brazil}

\author{
Modelagem hidrológica de bacia hidrográfica no semiárido do nordeste do Brasil \\ Modelización hidrológica de una cuenca hidrográfica en la región semiárida del noreste de Brasil
}

Received: 02/08/2022 | Reviewed: 02/15/2022 | Accept: 02/23/2022 | Published: 03/04/2022

\author{
João Marcos de Jesus Sales \\ ORCID: https://orcid.org/0000-0002-9997-4213 \\ Universidade Federal de Sergipe, Brasil \\ E-mail: salles.ufs@hotmail.com \\ Antenor de Oliveira Aguiar Netto \\ ORCID: https://orcid.org/0000-0002-3555-6776 \\ Universidade Federal de Sergipe, Brasil \\ E-mail: antenor.ufs@gmail.com \\ Clayton Moura de Carvalho \\ ORCID: https://orcid.org/0000-0002-4382-5382 \\ Instituto Federal de Educação, Ciência e Tecnologia Baiano, Brasil \\ E-mail: clayton.carvalho@ifbaiano.edu.br
}

\begin{abstract}
The use of hydrological models allows to understand, evaluate and anticipate events of natural or man-made origin in a simpler and more economical way for the quantity and quality of resources in a hydrographic basin. The present work aims to perform a hydrological modeling in the hydrographic basin in the semiarid, using the SWAT model, to verify the influence of the use and exploitation of water production on the land. For this, the SWAT hydrological model (Soil Water Assessment Tool) was used. A study area located in the Jacaré Curitiba Basin, in Poço Redondo-SE, a semi-arid region of the state, inserted in the Caatinga biome and in the lower São Francisco. The adopted methodology was used for bibliographic survey, field work, hydrological monitoring, chemical and physical medicine of soil and soil, survey of land use and exploration, calibration and validation of hydrological model. The SWAT model successfully simulated or hydrographed the flow for the period from Nov/2015 to Jul/2018, duly calibrated and validated. As simulations of different land use scenarios, the greatest production of water in agricultural areas stands out, which can cause greater generation of sediments. The calibrated and validated SWAT model means a possibility for future studies in nonsemiarid watersheds and then contributes to studies on water and soil management.
\end{abstract}

Keywords: Water resources; Water quality; Environmental monitoring; Anthropic activities; Irrigated agriculture.

\section{Resumo}

A utilização de modelos hidrológicos permite entender, avaliar e antecipar eventos de origem natural ou antrópicas de modo mais simples e econômico para a quantidade e qualidade dos recursos em uma bacia hidrográfica. $\mathrm{O}$ presente trabalho tem por objetivo realizar a modelagem hidrológica em bacia hidrográfica no semiárido, por meio da modelo SWAT, para verificar a influência do uso e ocupação da terra na produção de água. Para tal, foi utilizado o modelo hidrológico SWAT (Soil land Water Assessment Tool). A área de estudo está localizada na Bacia Escola Jacaré Curitiba, em Poço Redondo-SE, região semiárida do estado, inserida no bioma Caatinga e no baixo São Francisco. A metodologia adotada foi constituída de levantamento bibliográfico, trabalhos de campo, monitoramento hidrológico, análises físicoquímica da água e do solo, levantamento do uso e ocupação da terra, calibração e validação do modelo hidrológico. O modelo SWAT simulou com sucesso o hidrograma de fluxo para o período de nov/2015 a jul/2018, devidamente calibrado e validado. As simulações de diferentes cenários de uso da terra destacam a maior produção de água em áreas agrícolas, o que pode ocasionar maior geração de sedimentos. O modelo SWAT calibrado e validado significa uma possibilidade para estudos futuros em bacias hidrográficas no semiárido e, então, contribuir para estudos sobre manejo de água e solo.

Palavras-chave: Recursos hídricos; Qualidade da água; Monitoramento ambiental; Atividades antrópicas; Agricultura irrigada.

\section{Resumen}

El uso de modelos hidrológicos permite comprender, evaluar y anticipar eventos de origen natural o antrópico de una manera más sencilla y económica para la cantidad y calidad de los recursos en una cuenca hidrográfica. El presente trabajo tiene como objetivo realizar la modelización hidrológica en una cuenca hidrográfica de la región semiárida, utilizando el modelo SWAT, para verificar la influencia del uso y ocupación del suelo en la producción de agua. Para 
ello se utilizó el modelo hidrológico SWAT (Soil Land Water Assessment Tool). El área de estudio se ubica en la Cuenca Escola Jacaré Curitiba, en Poço Redondo-SE, en la región semiárida del estado, insertada en el bioma Caatinga y en el bajo São Francisco. La metodología adoptada consistió en levantamiento bibliográfico, trabajo de campo, monitoreo hidrológico, análisis físico-químico de aguas y suelos, levantamiento de uso y ocupación del suelo, calibración y validación del modelo hidrológico. El modelo SWAT simuló con éxito el hidrograma de flujo para el período de noviembre de 2015 a julio de 2018, debidamente calibrado y validado. Las simulaciones de diferentes escenarios de uso de la tierra destacan el aumento de la producción de agua en las áreas agrícolas, lo que puede conducir a una mayor generación de sedimentos. El modelo SWAT calibrado y validado significa una posibilidad para futuros estudios en cuencas hidrográficas en la región semiárida y, luego, contribuir a estudios sobre manejo de agua y suelos.

Palabras clave: Recursos hídricos; Calidad del agua; Monitoreo ambiental; Actividades antropogénicas; Agricultura de regadío.

\section{Introduction}

Inadequate management of water in quality and quantity in irrigation developed in arid and semi-arid regions can be associated with impacting situations, such as soil salinity, soil erosion and environmental pollution. Therefore, it is necessary to study the influence of irrigated agriculture, and its effects related to different use and occupation and what can bring risk to water sustainability.

In recent years, the issue of water resources in agricultural lands has been more frequently discussed, emphasizing the losses in quality and quantity when successive plantings are adopted, thus threatening water sustainability, especially in arid and semi-arid regions (Sales et al., 2020; Souza et al., 2021).

Among the main water consuming activities, agriculture is responsible for about $70 \%$, it is noteworthy that irrigated agriculture corresponds to less than $20 \%$ of the total cultivated area of the planet, but produces more than $40 \%$ of food, due to the population growth and the need for demand in the production of water and food at world level to serve about 9.8 billion inhabitants, population estimate for the year 2050, currently the world population is estimated at 7.74 billion inhabitants and that consumes over 4.5 billion liters of water per year (WWAP, 2017; WWAP, 2018; World Meters, 2019).

Small family farmers are the basis of food production in Brazil, with the implantation of irrigated perimeters in several places in Brazil and mainly in rainfed areas that allow ensuring the production of food at different times of the year. However, degradation rates were verified at global levels, related to natural or anthropic factors, in agricultural basins still correlated to changes in land cover, deforestation, runoff and nutrient level (Kristensen, 2012; Tsakiris, 2015, Ayala et al., 2016; Ordway et al., 2017). Previous studies carried out in the region of the irrigated perimeter prove the high concentrations of salinity and sodium in the soils in the irrigated rural settlement Jacaré Curituba (Santos \& Lucas, 2015, Sales et al., 2018; Lucas et al., 2019).

In this context, hydrological modeling in a hydrographic basin in the semiarid region of Northeast Brazil between the municipalities of Canindé do São Francisco and Poço Redondo in the State of Sergipe, more precisely in a school basin, allowed the adoption of techniques and monitoring of hydrological cycle variables. The basis of the structure proposed by Kobiyama et al. (2008), is for the school basin to exercise and provide the possibility of scientific research, extension activity, fieldwork and environmental education. This study is of crucial importance, besides monitoring and modeling of fundamental watersheds to monitor and evaluate the behavior of water resources.

The use of hydrological models is used to seek to represent the complexity of environmental systems in a simple way, allowing to assess the current state and simulate scenarios, this information will help understanding and decision making. Models are tools on the rise worldwide with diverse purposes. Among numerous hydrological models such as SWAT, Tank-Model, TopModel, Mike She, EPIC, AGPNS, they have been applied to predict the impact of soil management practices on the quality and quantity of water in a watershed (Oeurng et al., 2010; Celeste et al., 2014; Awan \& Ismaeel, 2014; Uniyal et al., 2017; Sivhare et al., 2018).

The SWAT model (Soil and Water Assessment Tool), was developed to understand the hydrological cycle processes, 
predict impacts and evaluate management practices on water resources, sediment production and agrochemicals in hydrographic basins, interpretation of the variation in use and land occupation and management practices over a long period of time (Neitsch et al., 2005).

The use of the SWAT hydrological model on a national scale was carried out for different purposes for the management of water resources, flood risks, determination of changes in land use and occupation, estimation of water availability, agricultural yield, pesticide dynamics, climate changes, analysis of water quality, water production, granting of rights to use water resources, hydrosedimentological dynamics (Souza et al., 2009; Durães Mello et al., 2011; Silva, 2013; Fukungana et al., 2015; Pereira et al., 2016; Silva et al., 2016; Brito et al., 2017; Silva et al., 2018a; Silva et al., 2018b; Fontes Júnior \& Montenegro, 2019).

The choice of the SWAT model implemented in this research through the geographic information system tool with the QuantumGis 2.6.1 Brighton software and the QSWAT interface used in this work, as it is the open SIG, and its availability and ease of use in data processing of entry, but also the possibility of reducing the hydrographic basin into smaller units, that is, the discretization of an area, where each of these, in turn, grouped with uniform soil characteristics, declivity and land use / occupation, are called Hydrological Response Units (HRUs) (Neitsch et al., 2005; Creech et al., 2015; Almeida, 2018).

Thus, the present work aims to perform hydrological modeling in a hydrographic basin in the semiarid region, using the SWAT model, to verify the influence of land use and occupation on water production.

\section{Methodology}

\section{Characterization of the study area}

The area of the present work is located in the semiarid region of Northeast Brazil, presenting an area of 327ha between the municipalities of Canindé do São Francisco and Poço Redondo. It lies in the northwestern portion of the State of Sergipe, 190km from the state capital, Aracaju (Sales et al., 2018). Figure 1 shows the location of the Jacaré Curituba School Basin and its geographical projection in the State of Sergipe and Brazil.

Figure 1. Map of land use and occupation, hidrography and the location of the study area in the State of Sergipe and Brazil.

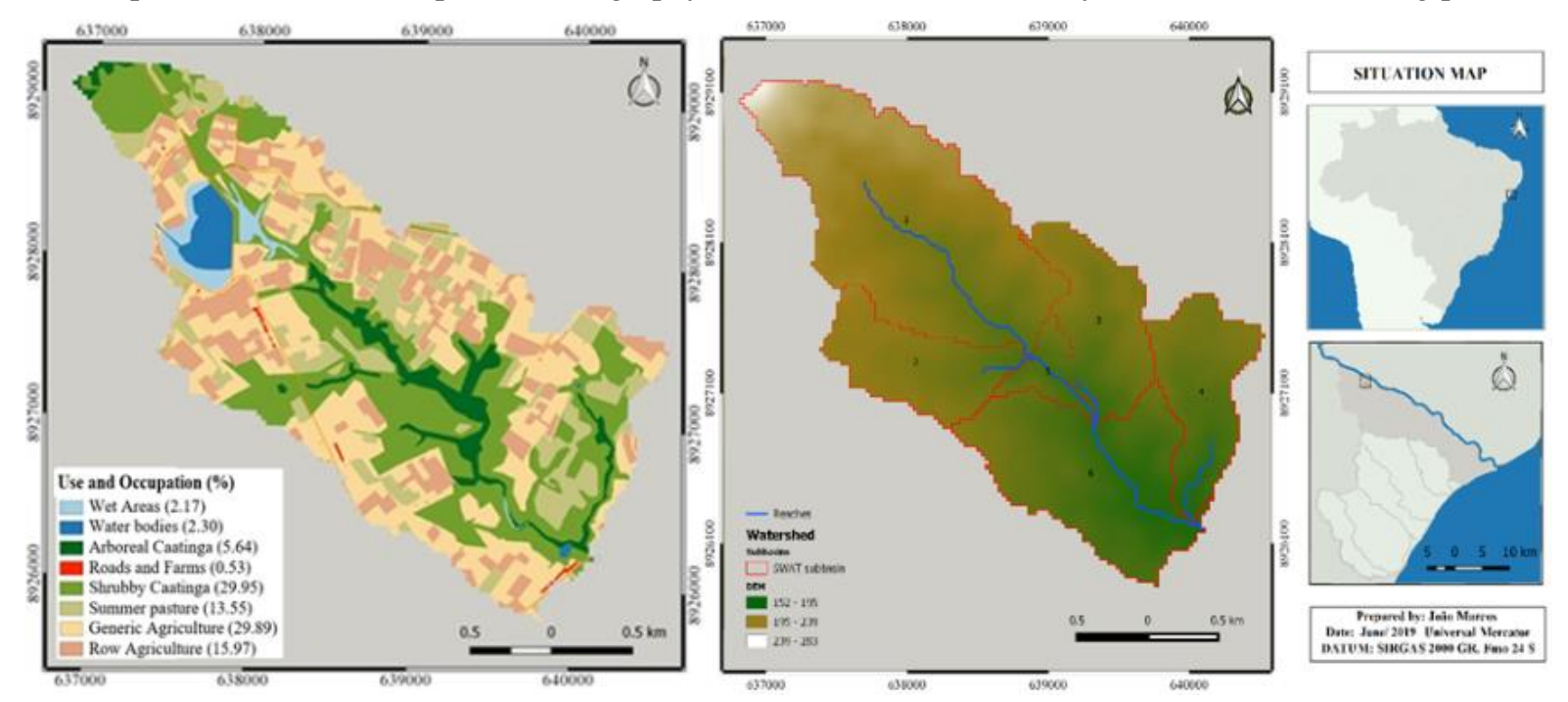

Source: Data from the research itself.

The School Basin was set up in 2015 to exercise and provide different audiences with the possibility of scientific research, fieldwork, extension activities and environmental education, located on a tributary stream of the Jacaré River, an important tributary of the right bank of the São Francisco River, this School Basin is located in the local Jacaré Curituba agrarian 
reform settlement that since 2010 has undergone changes with the installation of the irrigated perimeter of the same name, which has brought changes in the semiarid climate region, serving approximately 700 families of farmers, who started to produce several crops with emphasis on okra, cassava, corn and citrus through localized irrigation (Aguiar Netto et al., 2016).

The dominant native vegetation in the basin area is the hyperxerophyte caatinga. In this vegetation formation the presence of individuals of arboreal size is verified, alone or in small groups, with predominance of shrubs and low trees and a large number of cacti and bromeliads (Santos, 2001).

The soils in the Jacaré Curituba School Basin, according to the available data sources and field research, are classified as Luvisols. There is a predominance of Chromic Luvisol, which is a shallow soil, with a texture composed of high-activity clay, high fertility and chromic coloring. It is also observed the presence of rocky outcrops on the surface and in the profile, low infiltration speed, which contributes to restrictions on its use and propensity to erosion and salinization, this class represents the entire area occupied by the hydrographic basin (Santos et al., 2006; Sales et al., 2018).

The municipality of Poço Redondo where the School Basin is located has a predominance of hot and dry weather, according to the KOPPEN climatic classification, it is of the Bssh' type - very hot, semi-arid, steppe type climate, with rainy season in winter, with 7 to 8 dry months, where the average rainfall is below $700 \mathrm{~mm} /$ year, low and irregular, the potential evapotranspiration is greater than $1000 \mathrm{~mm}$ per year, with temperatures above 23 and $27^{\circ} \mathrm{C}$ according to the local office of the Agricultural Development of Sergipe - EMDAGRO (Sales et al., 2018).

\section{Monitoring Water Quantity}

The flow measurements were performed by means of a control point, or the exutory where all the runoff generated inside the Jacaré Curituba School Basin occurs. A Parshall gutter was installed during 2015, with daily monitoring starting in October of the same year. The daily measurements to obtain the flows made it possible to create a database with information on the water seasonality in this hydrographic basin. The Parshall gutter is a critical regime meter that combines a choke section right after the entry and in the recess and elevation of the meter bottom, obtaining a free flow regime. In this way, with the measurement of the liquid surface level at a single point, it is sufficient to determine the flow.

It should be noted that for this trough with a throat width equivalent to $0.152 \mathrm{~m}$, the equation was used:

$$
Q=0.381 x H^{1.580}
$$

where: $\mathrm{Q}=$ Flow rate $\left(\mathrm{m}^{3} \mathrm{~h}^{-1}\right) ; \mathrm{H}=$ Water depth $(\mathrm{m})$.

\section{Hydrological model road data}

The SWAT model requires the user to provide a series of information about the study area where the main steps and data source are detailed Table 1. The procedures were implemented with the geographic information system (GIS) tool using the QuantumGis 2.6.1 Brighton software and the QSWAT interface. 
Table 1. Source of input data for hydrological modeling of the Jacaré Curituba School Basin.

\begin{tabular}{|c|c|c|c|}
\hline DESCRIPTION & TYPE & DESCRIPTION & SOURCE \\
\hline Daily Precipitation & Tabular & Daily rainfall data $(\mathrm{mm})$. & $\begin{array}{c}\text { Xavier, (2015) } \\
\text { Canindé São Francisco-SE } \\
\text { Poço Redondo-SE (EMDAGRO e COHIDRO) }\end{array}$ \\
\hline $\begin{array}{l}\text { Climatological data } \\
\text { "weather } \\
\text { generator"SWAT }\end{array}$ & Tabular & $\begin{array}{l}\text { Monthly data on precipitation, } \\
\text { temperature, relative humidity, } \\
\text { wind speed and solar radiation. }\end{array}$ & $\begin{array}{l}\text { Climatic station of Pão de Açucar and Xavier, } \\
\text { (2015) (gridded). }\end{array}$ \\
\hline $\begin{array}{l}\text { Digital model of } \\
\text { Elevation }\end{array}$ & Map & $\begin{array}{c}\text { The map used } \\
\text { has scale } 1: 10,000\end{array}$ & SRTM TOPODATA $30 m$ \\
\hline Pedological map & Map & $\begin{array}{c}\text { The map used } \\
\text { has scale 1:50.000 }\end{array}$ & $\begin{array}{l}\text { EMBRAPA } \\
1: 250.000\end{array}$ \\
\hline $\begin{array}{l}\text { Usage map and } \\
\text { Occupation }\end{array}$ & Map & $\begin{array}{c}\text { The map used } \\
\text { has scale 1:50.000 }\end{array}$ & $\begin{array}{l}\text { MapBioma }(30 \mathrm{~m}) \text { in } 2019 \\
\text { Gaofen-2.(0.8m) in } 2019 .\end{array}$ \\
\hline Soil profile data & Tabular & $\begin{array}{l}\text { Physical and chemical } \\
\text { characteristics of the } \\
\text { soil for all profiles. }\end{array}$ & SALES et al., (2018) \\
\hline
\end{tabular}

Source: Data from the research itself.

The steps necessary to subdivide the hydrographic basin into several smaller basins and each of these, in turn, grouped with uniform characteristics of soil, slope and land use/occupation, are called Hydrological Response Units (HRUs). The number of sub-basins generated is based on the objectives and results to be obtained in the basin discretization procedure (Creech et al., 2015; Almeida, 2018).

The SWAT Model requires a digital elevation model (MDE) or also called a digital terrain model (MDT), a specific case of a numerical terrain model (MNT). The MDT used has a resolution of 30m, this data from the Topographic Radar Shuttle Mission (Shuttle Radar Topography Mission - SRTM) which was a space mission carried out on board the Endeavor spacecraft between February 11 and 22, 2000, traveling 176 orbits $233 \mathrm{~km}$ altitude, with a $57^{\circ}$ inclination, obtaining topographic data of approximately $80 \%$ of the terrestrial globe between latitudes $60^{\circ} \mathrm{N}$ and $56^{\circ} \mathrm{S}$, with band C, obtained from the Earthexplorer repository of the United States Department of Geology (USGS, 2018). Available from 2015 with a resolution of 30m, these images are necessary for the procedures to correct faults (empty or NoData) and outliers (extreme values, very high or very low) of the original raster files (digital image files formed by a series of "pixel" dots arranged in rows and columns) (NASA, 2018; Almeida, 2018).

According to Almeida (2018), some steps must be applied in most of the available Geographic Information Systems (GIS), where the first step is the removal of negative values through the use of a function present in the program where a new raster is created, this new file has only the quota values equal to or greater than zero, the lower values are left empty; In the second stage, a procedure for filling the voids is adopted, where the voids have been replaced by zero, through a raster reclassification procedure; In the third and last stage, new values are generated based on information from the nearest neighbors through an interpolation procedure, consisting of the replacement of the zeros and any outliers (Almeida, 2018).

The raster files with the generated MDTs are grouped in a single scene (Mosaic Procedure) and redesigned for a flat metric coordinate system. In the present study, the SIRGAS 2000 Mercator was adopted, which is the geodetic reference system adopted in America. In order to reduce the final size of the MDTs, they were also cut using a vector layer covering the area object of the research, the hydrographic basin of the Jacare River, plus a $5 \mathrm{~km}$ buffer in order to circumvent possible edge effects. Finally, in possession of the MDTs, it was possible to complete the design of the Jacaré Curituba School Basin after the definition of the control point of interest (inlets) exutory (Calha Parshall). 
The altimetric distribution present in the basin and types of landscape, is essential information for the application of the model, the slope classes to be treated, which in this research established those defined by EMBRAPA, that is, from $0^{\circ}$ to $3^{\circ}$ (flat terrain), from $3^{\circ}$ to $8^{\circ}$ (smooth wavy), from $8^{\circ}$ to $20^{\circ}$ (wavy), from $20^{\circ}$ to $45^{\circ}$ (strong-wavy) and above $45^{\circ}$ (mountainous and mountainous strong) (Santos et al., 2006).

Regarding the land use/occupation chart, considering that at first, obtained from MapBiomas, georeferenced, cut from the mask of the municipality Poço Redondo-SE and later the use and occupation of the soil was generated by digital orthophotography, the scenes to compose the mosaic to be created for the study area obtained from Sentinel-1A and Sentinel-1B with a pixel resolution of 10mx10m, obtained from the Earthexplorer repository of the United States Department of Geology (USGS, 2018). These orthophotos, georeferenced, with coordinates in the UTM projection, 24S spindle and horizontal SIRGAS 2000, were later treated and created the current uses and occupation present in the study area. As previously illustrated in Figure 1 (of that chapter). In relation to the identified coverages, a correlation of coverage was sought in the pre-existing database provided by SWAT.

The soil parameters were informed in the SWAT model for each of the layers (horizons) of each class of soil present in the study area. Table 2 lists and details each class of soil contained in the pedological map provided to the model.

Table 2. Soil parameters required for hydrological modeling of the Jacaré Curituba School Basin.

\begin{tabular}{|c|c|c|c|c|}
\hline NAME & DESCRIPTION & \multicolumn{3}{|c|}{ VALUE } \\
\hline SNAM & Soil name & \multicolumn{3}{|c|}{ Chromic Luvisolo } \\
\hline HYDGRP & Soil Hydrological Group (A, B, C or D) & \multicolumn{3}{|c|}{$\mathrm{D}$} \\
\hline NLAYERS & Number of layers & \multicolumn{3}{|c|}{3} \\
\hline SOL_ZMX & Maximum rooting depth $(\mathrm{mm})$ & \multicolumn{3}{|c|}{600} \\
\hline ANION_EXCL & Porosity fraction. & \multicolumn{3}{|c|}{0.52} \\
\hline SOL_CRK & Crack volume. & \multicolumn{3}{|c|}{$* 0.5$} \\
\hline TEXTURE & Soil texture & \multicolumn{3}{|c|}{ FRANCO ARGILOSO - CL } \\
\hline \multicolumn{2}{|c|}{ Camadas(layers) Brazilian system of soil classification } & $A$ & $B t$ & $C$ \\
\hline SOL_Z & Depth of soil layer surface (mm) & 200 & 200 & $600 *$ \\
\hline SOL_DB & Apparent density (wet) $\left(\mathrm{g} \mathrm{cm}^{-3}\right)$. & 1.23 & 1.25 & $1.48^{*}$ \\
\hline SOL_AWC & Available water capacity ( $\mathrm{mmH} 2 \mathrm{O} \mathrm{mm-1}$ soil). & 0.1099 & 0.1064 & $0.13 *$ \\
\hline SOL_K & Saturated hydraulic conductivity (mm h-1). & 8.0 & 4.19 & 4.6 \\
\hline SOL_CBN & Organic Carbon (\%) & 1.91 & 1.51 & $1.1^{*}$ \\
\hline SOL_CLAY & Clay $(\%)$ & 32.23 & 35.863 & $31.93 *$ \\
\hline SOL_SILT & Silte $(\%)$ & 31.6 & 32.223 & $32.28 *$ \\
\hline SOL SAND & Sand $(\%)$ & 36.172 & 31.914 & $36.92 *$ \\
\hline SOL_ROCK & Rock Fragments (\%) & 0 & 0 & $0 *$ \\
\hline SOL_ALB & Albedo & 0.16 & 0.212 & $0.281 *$ \\
\hline USLE K & Soil Erodibility Factor USLE & $0.124 *$ & $0.130 *$ & $* 0.146 *$ \\
\hline SOL_EC & Electric conductivity $\left(\mathrm{dS} \mathrm{m} \mathrm{m}^{-1}\right)$. & 4.70 & 3.2093 & $0 *$ \\
\hline
\end{tabular}

* - Data estimated by the SWAT - usersoil - PedoTransfer database. Source: Sales et al. (2018).

The SWAT_usersoil_PedoTransfer_template macro available on the (swat.tamu.edu) website was used to simulate soil data, where this macro was fed with real data. Since 2013, soils from the Jacare Curituba School Basin were collected and analyzed from 10 sampling sites, 7 of which were made available by Sales et al. (2018); and 3 of these sampling points collected during this research, analyzed according to the physical and chemical characteristics of the soils, In Table 2 the average of the main parameters required in the SWAT.

The SWAT model was properly fed with all the necessary data and all stages of HRU analysis were processed, as for the HRU definition stage, the cut ranges between soil types were determined by use/occupation by slope as follows: consider areas where use/occupation participate in at least $5 \%$ of the total area of the sub-basin, consider the types of soils that occupy at 
least $15 \%$ in relation to the total area of use/occupation of land and consider the slopes that affect at least $10 \%$ of soil types (Almeida, 2018).

The SWAT model requires climatic data for execution. However, there is no meteorological station in the study area, the nearest ones are located in Poço Redondo and Canindé do São Francisco, operated by the agricultural development company of Sergipe EMDAGRO and Sergipe Water Resources and Irrigation Company (COHIDRO) respectively. However, these stations were analyzed in this study only for the precipitation variable with the corresponding period from 2010 to 2018. Thus, the daily data of the five climatic variables required by the SWAT, made available from research of Xavier et al. (2015) throughout Brazil with the corresponding period from 1980 to 2016.

The meteorological parameters required for the SWAT climate generator are: TMPMN - Minimum temperature and TMPMX - Maximum temperature in the different months of the year $\left({ }^{\circ} \mathrm{C}\right)$ TMPSTDMN - Standard deviation of the minimum and TMPSTDMX - Standard deviation of the maximum temperature in the month; PCPD - Average number of rainy days in the month, PCPMM - Average precipitation in the month, PCPSKW - Skew coefficient for daily precipitation in the month, PCPSTD - Standard deviation of precipitation in the month RAINHHMX (maximum precipitation $0.5 \mathrm{~h}$ ) record for the month; PR_W1 Probability of a wet day (with rain) followed by a dry day in the month; PR_W2 - Probability of a wet day followed by another wet day in the month; SOLARAV - Average daily solar radiation in the month $\left(\mathrm{MJ} \mathrm{m}^{-2} \mathrm{day}^{-1}\right)$; WNDAV - Average daily wind speed in the month $\left(\mathrm{m} \mathrm{s}^{-1}\right)$ (Arnold et al., 2012), are shown in Table 3 .

Table 3. Climatic elements obtained from Xavier (2015) for the Jacaré Curituba School Basin.

\begin{tabular}{|c|c|c|c|c|c|c|c|c|c|c|c|c|}
\hline \multirow{2}{*}{$\begin{array}{l}\text { LATITUDE } \\
\text { Parameter }\end{array}$} & \multicolumn{2}{|c|}{$-9,6999$} & \multicolumn{2}{|c|}{ WLONGITUDE } & \multicolumn{2}{|c|}{$-37,7365$} & \multicolumn{2}{|c|}{ WELEV } & \multirow{2}{*}{$\begin{array}{l}192 \\
\text { Set }\end{array}$} & \multicolumn{2}{|c|}{ RAIN_YRS } & \multirow{2}{*}{$\begin{array}{c}37 \\
\text { Dec }\end{array}$} \\
\hline & Jan & Feb & Mar & Apr & May & Jun & Jul & Ago & & Oct & Nov & \\
\hline TMPMAX & 34.15 & 34.02 & 33.88 & 32.52 & 30.48 & 28.65 & 27.91 & 28.86 & 31.06 & 33.09 & 34.20 & 34.51 \\
\hline TMPMN & 22.69 & 22.86 & 23.02 & 22.63 & 21.73 & 20.64 & 19.82 & 19.55 & 20.25 & 21.27 & 22.17 & 22.64 \\
\hline TMPSTDMX & 1.96 & 2.00 & 2.03 & 2.15 & 2.07 & 1.65 & 1.56 & 1.75 & 2.03 & 1.98 & 2.02 & 2.02 \\
\hline TMPSTDMN & 0.92 & 07 & 0.00 & 0.83 & 0.90 & 0.91 & 1.02 & 1.04 & 1.04 & 0.93 & 0.93 & 0.85 \\
\hline РСРММ & 42.94 & 40.01 & 59.72 & 52.65 & 70.22 & 77.68 & 79.58 & 45.22 & 23.95 & 16.84 & 15.58 & 25.79 \\
\hline PCPSTD & 5.07 & 4.00 & 5.08 & 3.75 & 3.90 & 3.98 & 3.58 & 2.55 & 2.11 & 2.72 & 2.15 & 3.18 \\
\hline PCPSKW & 7.23 & 5.38 & 4.93 & 4.34 & 3.05 & 3.14 & 3.01 & 4.78 & 6.17 & 11.77 & 6.76 & 7.30 \\
\hline PR_W1 & 0.22 & 0.21 & 0.25 & 0.30 & 0.35 & 0.57 & 0.46 & 0.41 & 0.21 & 0.11 & 0.12 & 0.13 \\
\hline PR_W2 & 0.57 & 0.63 & 0.70 & 0.76 & 0.80 & 0.85 & 0.87 & 0.81 & 0.71 & 0.56 & 0.53 & 0.61 \\
\hline PCPD & 10.73 & 10.89 & 14.81 & 17.32 & 20.84 & 24.92 & 25.38 & 22.46 & 13.57 & 6.81 & 6.62 & 8.46 \\
\hline RAINHHMX & 21.71 & 17.54 & 18.22 & 13.95 & 10.14 & 10.94 & 13.16 & 10.46 & 11.21 & 19.47 & 8.20 & 14.53 \\
\hline SOLARAV & 22.25 & 22.13 & 21.34 & 19.29 & 16.40 & 14.69 & 15.13 & 17.64 & 20.80 & 23.11 & 23.65 & 22.95 \\
\hline DEWPT & 22.07 & 22.34 & 22.97 & 23.07 & 22.51 & 21.72 & 20.91 & 20.67 & 20.86 & 21.27 & 21.48 & 21.81 \\
\hline WNDAV & 2.71 & 2.52 & 2.38 & 2.27 & 2.09 & 2.13 & 2.24 & 2.45 & 2.75 & 2.90 & 2.87 & 2.77 \\
\hline
\end{tabular}

Source: Data from the research itself.

In the present study, free softwares were used, such as Qgis and the R language, in the RSTUDIO and RCOMMANDER environment (Allaire, 2018) to format the data in the SWAT standard.

\section{Calibration/validation and statistics used}

Calibration and data validation is essential when using hydrological models, calibration is necessary to make the model as consistent as possible and reduce the uncertainties of the results, in this step of minimizing the deviations between the simulated and measured variables, while the validation is the verification of a model by comparing the modeled data with those 
obtained by observation or measured in the real system for a different data period than the one used in the calibration (Arnold et al., 2012; Silva, 2013; Salazar, 2016; Brito, 2017; Almeida, 2018).

In the calibration process of the SWAT model, the simulated results were compared in relation to the historical flows recorded by the Parshall channel. The SWAT model was calibrated with the help of the SWAT-CUP Software (TAMU, 2018a and TAMU, 2018b), also used for the sensitivity analysis by Silva (2013), Salazar (2016), Brito (2017) and Almeida (2018). The application of SWAT-CUP followed the methodology described by Abbaspour (2012).

The available flow data series were divided into two periods, one for calibration and one for validation. The tools for the graphical comparison and the statistical criteria used to assess the calibration of the SWAT model, are defined by the following mathematical expressions:

1. NSE-Nash-Sutcliffe efficiency:

$$
\mathrm{NSE}=1-\frac{\sum_{i=1}^{N}(S i-O i)^{2}}{\sum_{i=1}^{N}(O i-\bar{O})^{2}}
$$

Where: $O i=$ observed event; $S i=$ simulated event; $\bar{O}=$ average of the events observed in the simulation period.

The NSE values vary between $-\infty$ and 1 , the unit being the value for which the simulated data are perfectly suited to the observations. Values between 0 and 1 are generally considered to be acceptable (Moriasi et al., 2007; Silva, 2013; Almeida, 2018).

2. PBIAS-Percentage Trend:

$$
\text { PBIAS }=100 \frac{\sum_{i=1}^{N}(S i-O i)}{\sum_{i=1}^{N} O i}
$$

For an optimal relationship, PBIAS is equal to zero, and small magnitude values indicate good adjustments. Positive values indicate an overestimation of the simulated values while negative values indicate an underestimation of the simulated values (Moriasi et al., 2007; Silva, 2013; Almeida, 2018).

3. RSR-Normalization of the root of the mean square error by the standard deviation of the observed series:

$$
\mathrm{RSR}=\frac{\sqrt{\sum_{i=1}^{N}(S i-O i)^{2}}}{\sqrt{\sum_{i=1}^{N}(O i-\bar{O})^{2}}}
$$

The RSR coefficient incorporates the statistical benefits of the error indices and includes a scale / normalization factor, so that the resulting statistical values are reported and applied in the consistency assessment. RSR varies between the ideal value 0 (zero) and values greater than 0.7 unsatisfactory (Moriasi et al., 2007; Silva, 2013; Almeida, 2018; Ferreira et al., 2022).

The intervals were compared considering the maximum and minimum intervals to maintain the reasonable output values proposed by Moriasi et al. (2007) and Silva (2013) according to Table 4.

Table 4. Criteria for assessing the performance of hydrological models and their respective classifications.

\begin{tabular}{cccc}
\hline CLASSIFICATION & NS & PBIAS & RSR \\
\hline Unsatisfactory & $\mathrm{NS} \leq 0.50$ & PBIAS $\geq \pm 25$ & RSR $>0.70$ \\
Satisfactory & $0.50<\mathrm{NS} \leq 0.65$ & $\pm 15 \leq$ PBIAS $<25 \pm$ & $0,60 \leq \mathrm{RSR} \leq 0.70$ \\
Good & $0.65<\mathrm{NS} \leq 0.75$ & $\pm 10 \leq$ PBIAS $<15 \pm$ & $0.50 \leq \mathrm{RSR} \leq 0.60$ \\
Very good & $0.75<\mathrm{NS} \leq 1.00$ & PBIAS $< \pm 10$ & $0.00 \leq \mathrm{RSR} \leq 0.50$ \\
\hline
\end{tabular}

Source: Adapted from Moriasi et al. (2007) and Silva (2013). 
For the evaluation and simulation of land cover scenarios, four scenarios were used to assess the effect of changes in land cover on surface runoff. Land cover and scenarios were: (A) scenario I (current use), this area corresponds to the current land use, (B) scenario II (Caatinga), the current use has been replaced by vegetation - Caatinga (forest area or vegetation recovery); (C) scenario III, (Pastures) the current use has been changed to pastures, (D) scenario IV (Agriculture) the current use has been replaced by agriculture. The choice of these different scenarios for comparison with current uses, can be useful in the decision making of the different actors present in the basin, for the conservation of natural resources and to recover degraded areas.

\section{Results and Discussion}

The sensitivity analysis was performed based on a bibliographic review and the documentation of the SWAT hydrological model (Abbaspour, 2012), and twelve parameters were then selected that were used for calibration purposes (Arnold et al., 2012; Brito et al., 2017; Almeida, 2018). Finally, the sensitivity analysis procedure developed by means of initial simulation, using observed and simulated data according to the characteristics of each parameter, the values in the calibration process and sensitivity analysis, change within the lower and upper limits established, this analysis was possible through modification by multiplication or substitution, in relation to the initial value (Van Griensven et al., 2006).

The manual calibration of the parameters that influence the underground flow and runoff have been optimized. Some of these are difficult to measure, the parameters for measuring the length of time that the water moves from the deepest soil layer to the top aquifer (GW_DELAY), runoff coefficient "movement" of water from the top aquifer to unsaturated zone (GW_REVAP), base runoff factor, rate at which groundwater returns to the river (ALPHA_BF), value of the number curve for humidity condition II (CN), available water capacity in the soil (SOL_AWC), and compensation coefficient of evaporation of water from the soil (ESCO), leading the response of the runoff to the flow variable were more sensitive because they have an effect on the simulation of the observed and simulated daily flow data.

For the Jacare Curituba watershed, the base runoff factor, the rate at which groundwater returns to the ALPHA_BF river was (0.95 days), a similar situation in the calibration stage was highlighted by Blainski et al. (2017), the ALPHA_BF parameter where the value was (0.6). Fontes Junior \& Montenegro (2019), on the other hand, analyzed modeling in a hydrographic basin in a semi-arid region of Northeast Brazil and the value found in the daily manual calibration ALPHA_BF (0.85).

In the present study, the calibrated value of the average number $(\mathrm{CN})$ curve for the Jacare Curituba school basin was $83.75 \%$, this parameter can be adjusted for the different land uses that include summer pasture (SPAS), Caatinga Arbórea (SWRN), Caatinga Shrubs (RNGB), Agrovilas (URLD), Row crops (AGRR) and Generic crops (AGRL), the largest percentage of the basin is occupied by agriculture.

According to Brouziyne et al. (2017) in a study developed in a hydrographic basin in Morocco, with similar characteristics of climate, soils and above 50\% occupied by irrigated and rainfed agriculture, the authors found a value of curve number $(\mathrm{CN})$ 82.6\%. The CN value $82.97 \%$ for modeling on the river Ganga, in India developed by Shivhare; Dikshit and Dwivedi, (2018) corroborating the values found in this research. Andrade et al. (2019) performing hydrological modeling in the Mundaú River basin in Northeastern Brazil, rural basin with agricultural activities and Caatinga and Atlantic Forest vegetation registered the $\mathrm{CN}$ value $73.7 \%$ and, according to the authors, the characteristics of the hydrographic basin, hydrological group, soil type, land use and management, among other factors are reflected in the number curve.

Table 5 shows the criteria for assessing the performance of the hydrological model and their respective statistical classifications for the calibrated and validated model. There is a difference in the observed flows compared to the simulated ones, in which the difference is explained by PBIAS, values positives show overestimation of simulations and negatives indicate 
underestimation. As for the standard deviation, the simulated data obtained a lower value indicating that the model smoothes the variation in flow rates.

Table 5. Statistical evaluations of the daily flow calibration in the period November 2015 to October 2017 and for the validation of the daily flow in the period November 2017 to July 2018 for the hydrological modeling of the Jacaré Curituba School Basin.

\begin{tabular}{|c|c|c|c|c|c|c|}
\hline \multicolumn{3}{|c|}{ Basic Statistics of Flow Data } & \multicolumn{4}{|c|}{ Model evaluation statistics } \\
\hline Description & Observed & Simulated & Statistic & $\begin{array}{c}\text { Calibration } \\
\text { Value }\end{array}$ & Validation Value & Performance \\
\hline Total & $81.85 \mathrm{~m}^{3} \mathrm{~s}^{-1}$ year $^{-1}$ & $76.79 \mathrm{~m}^{3} \mathrm{~s}^{-1}$ year $^{-1}$ & NSE & 0.66 & 0.57 & Good/Satisfactory \\
\hline Average & $0.24 \mathrm{~m}^{3} \mathrm{~s}^{-1}$ & $0.22 \mathrm{~m}^{3} \mathrm{~s}^{-1}$ & PBIAS & -20.18 & -17.18 & Satisfactory \\
\hline Desv. Pad. & $0.52 \mathrm{~m}^{3} \mathrm{~s}^{-1}$ & $0.51 \mathrm{~m}^{3} \mathrm{~s}^{-1}$ & RSR & 0.59 & 0.62 & Satisfactory \\
\hline
\end{tabular}

Source: Data from the research itself.

Regarding the Nash-Sutcliffe Efficiency (NSE), this resulted in a good result of 0.66 for the calibration period and a satisfactory 0.57 for the validation period. Values above 0.5 are classified as accepted, and the reduction of the index in the validation period is common (Moriasi et al., 2007; Fukunaga et al., 2015; Fontes Junior \& Montenegro, 2019). The percentage trend (PBIAS) both were classified as satisfactory, with -20.18 for PBIAS during calibration and -17.18 during the validation period, it is emphasized that negative PBIAS values indicate underestimation of the simulated values (Moriasi et al., 2007; Silva, 2013; Almeida, 2018) and the normalization of the root of the mean square error (RSR) 0.59 in the calibration and 0.62 in the validation. For Moriasi et al. (2007) it is commonly accepted that the lower the RSR, the better the simulation performance of the model, value $>0.7$ are unsatisfactory.

These calibrated and validated values correspond to those found by other studies of the recharge estimate using the SWAT. Similar results were obtained by Mello et al. (2017) in a hydrographic basin in Sarapuí, São Paulo State, Brazil, which obtained better results for calibration $(\mathrm{NSE}=0.65$, PBIAS $=-12.7)$ than for validation $(\mathrm{NSE}=0.56, \mathrm{PBIAS}=19.1)$. Fontes Junior and Montenegro (2019) also studied a hydrographic basin in Northeast Brazil, the values found determined better results for the daily calibration NSE (0.77) was very good, than for the validation (0.55) considered as satisfactory. In the hydrograph in Figure 2, the calibration and validation process is verified, the model performed the forecast properly, a good fit is visualized.

Figure 2. Adjustment of calibration and validation based on the hypothesis of affluence in the hydrological modeling of the Jacaré Curituba School Basin.

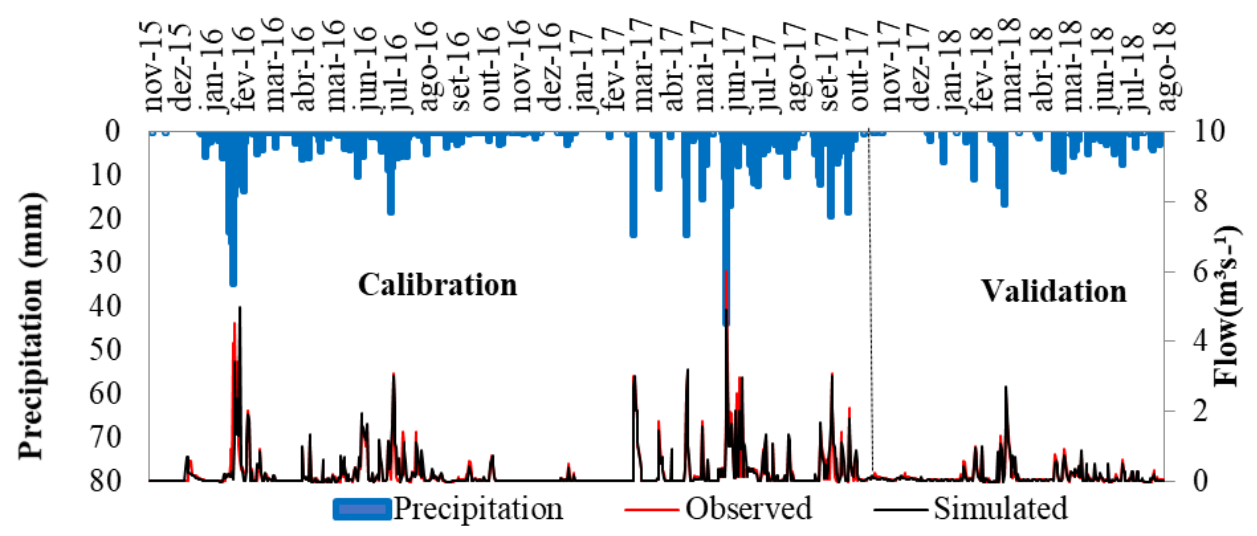

Source: Data from the research itself.

The output data for flow analysis observed and simulated, the minimum minimum flow values and peak values proportional to the observed precipitation rates of the model were observed in the comparison, it was satisfactory, 
The water balance analysis resulting from the SWAT simulation for the Jacare Curituba School Basin can be seen (Appendix C) and in the synthesis of Figure 3, and the illustration of these simulated hydrological processes reveal that the average annual precipitation of the Jacaré Curituba School Basin was equal to $587.3 \mathrm{~mm}$, actual evapotranspiration (452.1 mm year $\left.^{-1}\right)$ and potential evapotranspiration $\left(1,309.5 \mathrm{~mm}^{-1} \mathrm{ye}^{-1}\right)$ were also observed, with a rise in the shallow aquifer $(26.19 \mathrm{~mm}$ year $\left.^{-1}\right)$, percolation for the shallow aquifer $\left(71.13 \mathrm{~mm}_{\text {year }}^{-1}\right)$, with runoff $\left(53.18 \mathrm{~mm}^{-1} \mathrm{ear}^{-1}\right)$, lateral flow $\left(0.76 \mathrm{~mm}\right.$ year $\left.{ }^{-1}\right)$, and the average Curve Number $(\mathrm{CN})$ was $83.75 \%$.

Figure 3. SWAT average water balance calibrated for the Jacaré Curituba School Basin.

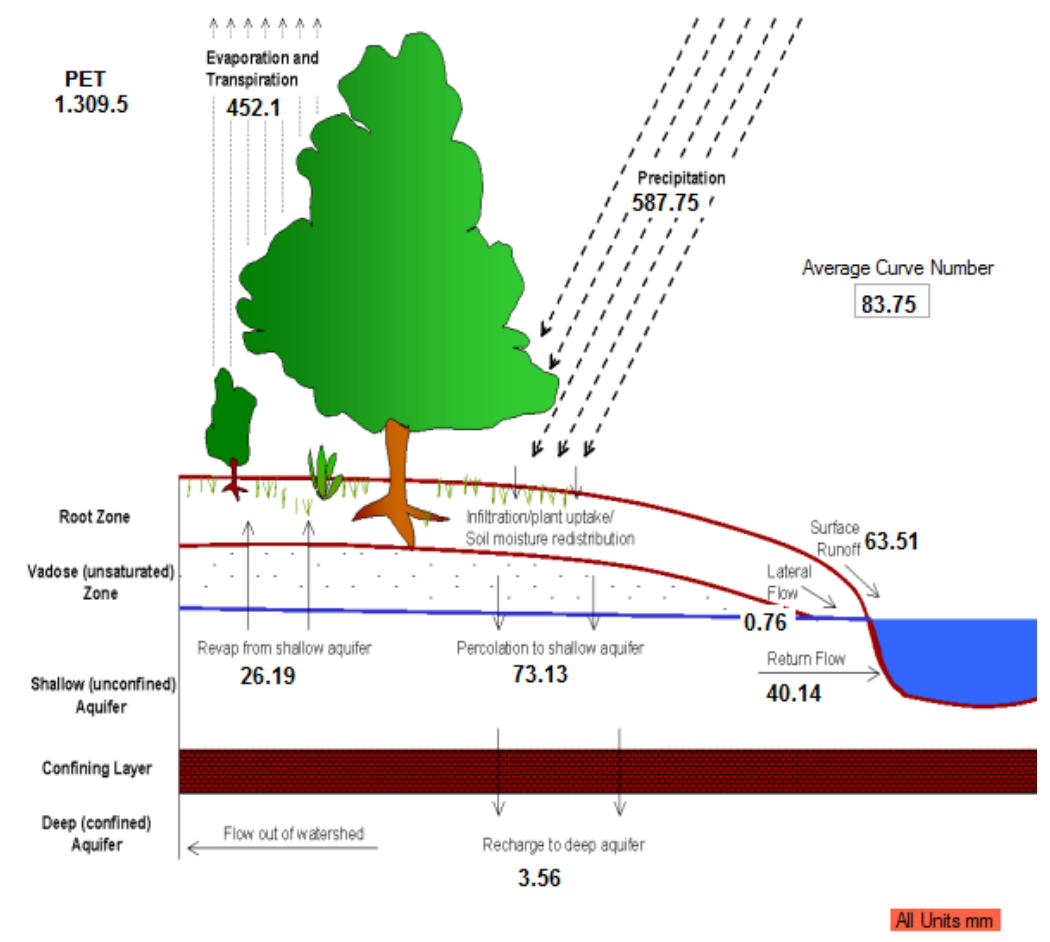

Source: Data from the research itself.

The results found in this work, are similar to the results of the hydrological modeling found by Andrade et al. (2017) in a hydrographic basin in the Northeast region between the states of Alagoas and Pernambuco, where the value: Curve Number (CN) $77.74 \%$; real evapotranspiration (ET) $548.2 \mathrm{~mm} \mathrm{year}^{-1}$; potential evapotranspiration (PET) or references $1,262.8 \mathrm{~mm}^{2} \mathrm{year}^{-}$ ${ }^{1}$ and for ascension of the shallow aquifer $25.26 \mathrm{~mm}$ year $^{-1}$.

The results of simulations in the three scenarios described in the methodology and the current land use are shown in Figure 4, and the SWAT hydrological model was used to estimate changes in water production due to changes in land use for the period of 2015 to 2018 , after the calibration and validation processes. 
Figure 4. Map of the average annual distribution of water production for 2016 in the Jacaré Curituba School Basin.

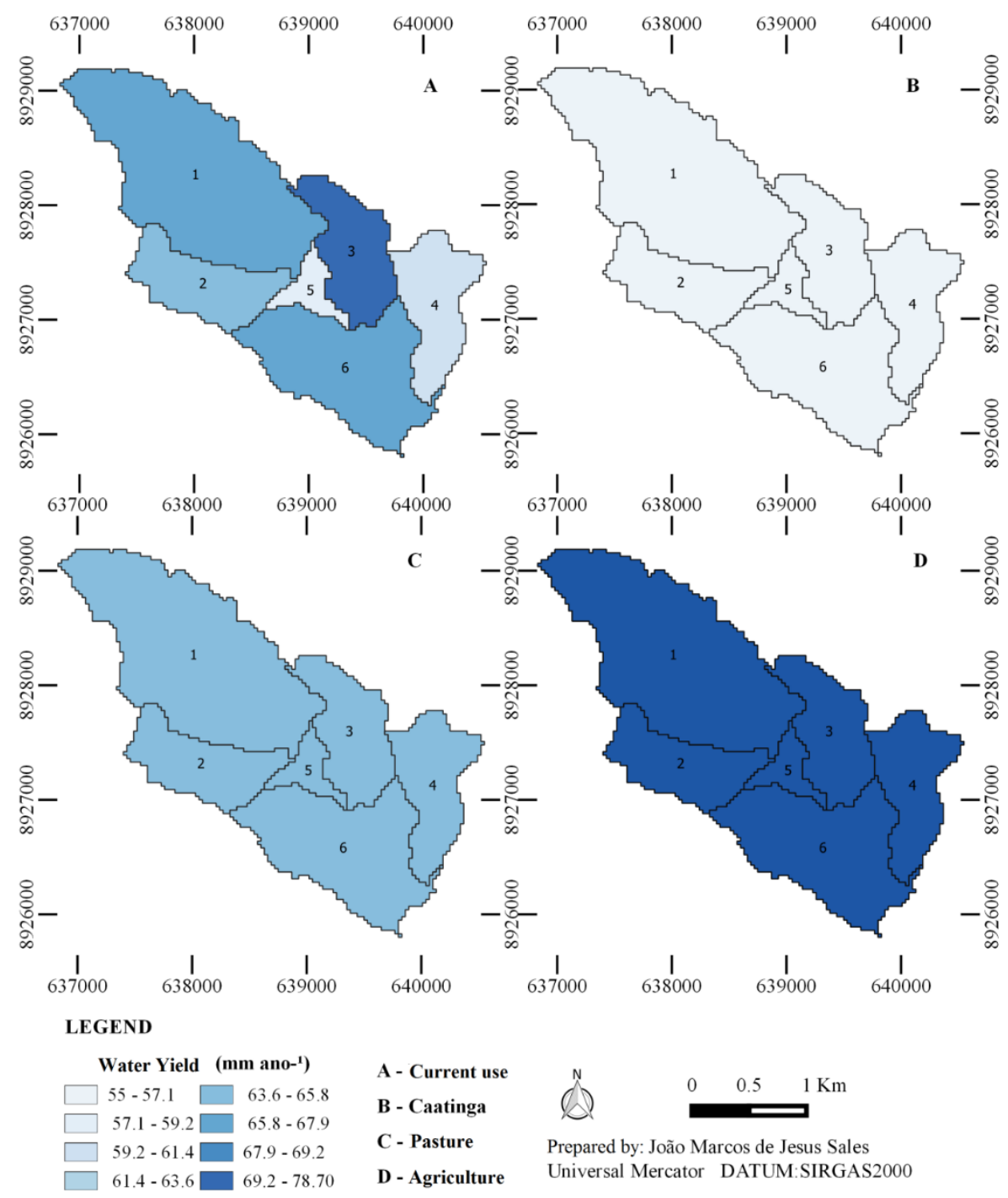

Source: Data from the research itself.

In the Figure 4 analysis, the results exposed for the sub-basins and scenarios are represented by color difference. They show average water production values (Figure 4A) ranging from 58.65 to $70.24 \mathrm{~mm}_{\text {year }}{ }^{-1}$. Sub-basin 3 with an occupancy rate above $70 \%$ by agriculture showed the highest water production value $\left(70.24 \mathrm{~mm} \mathrm{year}^{-1}\right)$, while the lowest production was recorded in sub-basin 5 (58.65 $\left.\mathrm{mm}^{-1} \mathrm{ye}^{-1}\right)$ mainly occupied by arboreal (17.56\%) and shrub (56.1\%). The average production of current use (Figure 4A) is equivalent to $64.99 \mathrm{~mm} \mathrm{year}^{-1}$, a performance superior to the values measured by Aguiar Netto et al. (2016), in the hydrographic basin of the Jacaré River.

Scenario I (Figure 4B) that simulates the replacement of current use by Caatinga, (Reforestation and preservation of native and riparian forest), presented the lowest rate in runoff, showing values between 55.08 and $57.78 \mathrm{~mm}^{\mathrm{year}}{ }^{-1}$. It is verified in the literature that different researches show that areas of native or regenerated forests are an interesting alternative to reduce sediment transport influenced by roughness and increased infiltration rate, thus reducing runoff (Larson, 1997; Aragão et al., 2013; Silva et al., 2016; Silva et al., 2018a).

The impact of changes in land use and occupation across the Jacaré Curituba School Basin by pastures was investigated using scenario II (Figure 4C), resulting in average values between 63.8 and $66.64 \mathrm{~mm}^{-1}$, therefore higher than scenario I. Scenario III, that is, the occupation of the entire hydrographic basin by agriculture shows an average water production between 
70.06 to $78.70 \mathrm{~mm} \mathrm{year}^{-1}$. Silva et al. (2018a), using the SWAT model, observed the lowest water production in an area with Caatinga and the scenario with agriculture being the largest production of sediments and runoff.

\section{Conclusion}

The results of calibration and validation of the SWAT hydrological model show satisfactory and good performance for simulating the flow in a hydrographic basin in the semi-arid, which allows us to conclude that the largest water production occurs in agricultural areas, which can cause erosion problems.

The calibrated and validated SWAT model means a possibility for future studies in hydrographic basins in the semiarid region and, therefore, to contribute to studies on water and soil management.

\section{Acknowledgments}

Project Opará: águas do rio São Francisco, executed by Federal University of Sergipe and Socio-environmental Canoa de Tolda, sponsored of Petrobras by the Petrobras Socio-environmental Program.

\section{References}

Abbaspour, K. C. (2012). SWAT-CUP-2012: SWAT Calibration and Uncertainty program - A User Manual. Dübendorf: Swiss Federal Institute of Aquatic Science and Technology, 100p.

Aguiar Netto, A. O., Santana, L. L., Almeida, C. A. P., Faccioli, G. G., \& Sales, J. M. J. (2016). Efeito da variabilidade de cenários de uso do solo sobre a dinâmica da vazão e de sedimentos na bacia hidrográfica do rio Jacaré-SE. In: FAPITEC. (Org.). Pesquisa em políticas públicas no estado de Sergipe. São Cristóvão: EDUFS, p.267-280.

Allaire, J. J. (2018). RStudio. https://www.rstudio.com.

Almeida, C. A. P. (2018). Prospecção da Crise Hídrica por meio da Modelagem Hidrológica no rio São Francisco. Tese de Doutorado em desenvolvimento e meio ambiente. São Cristóvão: UFS, 200p.

Andrade, C. W. L., Montenegro, S. M. G. L., Lima, J. R. S., Montenegro, A. A. A., \& Magalhães, A. G. (2017). Modelagem hidrológica sob mudanças na cobertura vegetal de uma bacia hidrográfica no Nordeste do Brasil. Journal Environmental Analysis and Progress, 2(3), 239-248. http://dx.doi.org/10.24221/jeap.2.3.2017.1446.239-248

Andrade, C. W. L., Montenegro, S. M. G. L., Montenegro, A. A. M., Lima, J. R. S., Srinivasan, R., \& Jones, C. A. (2019). Soil moisture and discharge modeling in a representative watershed in northeastern Brazil using SWAT. Ecohydrology \& Hydrobiology, 19(2), 237-250. https://doi.org/10.1016/j.ecohyd.2018.09.002

Aragão, R., Cruz, M. A. S., Amorim, J. R. A., Mendonça, L. C., Figueiredo, E. E., \& Srinivasan, V. S. (2013). Análise de sensibilidade dos parâmetros do modelo SWAT e simulação dos processos hidrossedimentológicos em uma bacia no agreste nordestino. Revista Brasileira de Ciência do Solo, 37(4), 1091-1102. https://doi.org/10.1590/S0100-06832013000400026.

Arnold, J. G., Kiniry, J. R., Srinivasan, R., Williams, J. R., Haney, E. B., \& Neitsch, S. L. (2012). Soil and Water Assessment Tool input/output file documentation: Version 2012. Texas Water Resources Institute TR 436. 654p. http://swatmodel.tamu.edu/documentation

Awan, U. K., \& Ismaeel, A. (2014). A new technique to map groundwater recharge in irrigated areas using a SWAT model under changing climate. Journal of. Hydroly, 519, 1368-1382. https://doi.org/10.1016/j.jhydrol.2014.08.049

Ayala, L. M., Eupen, M. V., Zhang, G., Perez-Soba, M., Martorano, L. G., Lisboa, L. S. S., \& Beltrao, N. E. (2016). Impact of agricultural expansion on water footprint in the Amazon under climate change scenarios. Science of the Total Environment, 569-570, 1159-1173. https://doi.org/10.1016/j.scitotenv.2016.06.191

Blainski, E., Acosta, E., \& Nogueira, P. C. P. (2017). Calibração e validação do modelo SWAT para simulação hidrológica em uma bacia hidrográfica do litoral norte catarinense. Revista Ambiente \& Água, 12(2), p.226-237. https://doi.org/10.4136/ambi-agua.1951.

Brito, F. B., Aguiar Netto, A. O., Vasco, A. N., \& Silva, G. M. (2017). Aplicação do modelo SWAT para avaliar o potencial de contaminação por agrotóxicos num afluente do rio São Francisco, Brasil. Scientia Plena, 13(10), 1-15.

Brouziyne, Y., Abouabdillah, A., Bouabid, R., Benaabidate, L., \& Oueslati, O. (2017). SWAT manual calibration and parameters sensitivity analysis in a semiarid watershed in North-western Morocco. Arabian Journal. Geosciences, 10(427). https://doi.org/10.1007/s12517-017-3220-9

Celeste, A. B., Menezes, T. N., \& Fontes, V. (2014). Modelagem do processo chuva-vazão pelo Tank Model e por redes neurais artificiais na bacia do rio Japaratuba, Sergipe. Scientia Plena, 10(7), 073301. https://www.scientiaplena.org.br/sp/article/view/1802

Creech, C.T., Siqueira, R. B., Selegean, J. P., \& Miller, C. (2015). Anthropogenic impacts tothe sediment budget of São Francisco River navigation channel using SWAT. International Journal of Agricultural and Biological Engineering, 8(3), 140-157. https://ijabe.org/index.php/ijabe/article/view/1372/pdf 
Durães, M. F., Mello, C. R., \& Naghettini, M. (2011). Applicability of the SWAT model for hydrologic simulation in Paraopeba river basin, MG. Cerne, 17(4), 481-488. https://doi.org/10.1590/S0104-77602011000400006

Ferreira, E. C.., Silva, A. C.., Cabral, J. J. S. P., \& Azevedo, J. R. G. (2022). Avaliação dos parâmetros hidrológicos da bacia do Rio Goiana no Estado de Pernambuco utilizando ferramenta de calibração automática do modelo hidrodinâmico PCSWMM em múltiplas estações fluviométricas. Research, Society and Development, 11(2), e15011225331. https://doi.org/10.33448/rsd-v11i2.25331

Fontes Júnior, R., \& Montenegro, A. (2019). Impact of land use change on the water balance in a representative watershed in the semiarid of the state of Pernambuco using the swat model. Engenharia Agrícola, 39(1), 110-117. https://doi.org/10.1590/1809-4430-Eng.Agric.v39n1p110-117/2019

Fukunaga, D. C., Cecílio, R. V., Zanetti, S. S., Oliveira, L. T., \& Caiado, M. A. C. (2015). Application of the SWAT hydrologic model to a tropical watershed at Brazil. Catena, 125, 206-213. https://doi.org/10.1016/j.catena.2014.10.032

Kobiyama, M., Chaffe, P. L. B., Rocha, H. L., Corseuil, C. W., \& Malutta, S. (2008). School catchments network in the Upper Negro River basin, southern Brazil: Scientific research and environmental education. Anais... In: Oficina Internacional sobre Enfoques Regionais para o Desenvolvimento e Gestão de Reservatórios na Bacia do Prata, 5, Foz do Iguaçu: UNESCO/ICHARM/UNEP, 2008.

Kristensen, P. (2012). European Waters: Assessment of Status and Pressures. European Environmental Agency, Copenhagen.

Larson, W. E., Lindstrom, M. J., \& Schumacher, T. E. (1997). The role of severe storms in soil erosion: a problem needing consideration. Journal of Soil and Water Conservation, 52(2), 90-95. https://www.jswconline.org/content/52/2/90

Lucas, A. A. T., Farias, D. B. S., Santos S. J. S., Silva, A. J., Aguiar Netto, A. O., \& Araújo, R. R. (2019). Recuperação de solo salino-sódico no semiárido brasileiro. In: Aguiar Netto, A. O., Lima, A. V. O., \& Santos, T. I. S. (Org.). Opará. Aracaju: Criação Editora, 135-146.

Mello, K.; Randhir, T. O., Valente, R. A., \& Vettorazzi, C. A. (2017). Riparian restoration for protecting water quality in tropical agricultural watersheds. Ecological Engineering, 108, 514-524. https://doi.org/10.1016/j.ecoleng.2017.06.049

Moriasi, D. N., Arnold, J. G., Van Liew, M. W., Bingner, R. L., Harmel R. D., \& Veith, T. L. (2007). Model evaluation guidelines for systematic quantification of accuracy inwatershed simulations. Transactions of the ASABE: St. Joseph, 50(3), 885-900.

NASA. Jet Propulsion Laboratory (JPL). (2018). National Aeronautics and Space Administration (NASA). https://www.jpl.nasa.gov/news.php?release=2014321.

Neitsch, S. L., Arnold, J. G., Kiniry, J. R., \& Williams, J. R. (2005). Soil and water assessment tool: Theoretical documentation - version 2005. (2005). Temple: Grassland, Soil and Water Research Laboratory, Agricultural Research Service, 494p. https://swat.tamu.edu/media/1292/SWAT2005theory.pdf

Oeurng, C., Sauvage, S., \& Sánchez-Pérez, J. M. (2010). Dynamics of suspended sediment transport and yield in a large agricultural catchment, southwest France. Earth Surface Processes and Landforms, 35(11), 1289-1301. https://doi.org/10.1002/esp.1971

Ordway, E. M., Asner, G. P., \& Lambin, E. F. (2017). Deforestation risk due to commodity crop expansion in sub-Saharan Africa. Environmental Research Letters, 12(4), 044015. https://doi.org/10.1088/1748-9326/aa6509

Pereira D. R., Martinez, M. A., Pruski, F. F., \& Silva, D. D. (2016). Hydrological simulation in a basin of typical tropical climate and soil using the SWAT model part I: Calibration and validation tests. Journal of Hydrology: Regional Studies, 7, 14-37. https://doi.org/10.1016/j.ejrh.2016.05.002

Salazar, R. D. C. (2016). Modelagem hidrossedimentológica da bacia hidrográfica do rio Betume, Baixo São Francisco Sergipano. Dissertação de Mestrado em recursos hídricos. São Cristóvão: UFS, 84p.

Sales, J. M. J., Aguiar Netto, A. O., Monteiro, A. S. C., \& Carvalho, C. M. (2020). Variabilidade espaço-temporal da qualidade da água em área de agricultura irrigada. Revista Brasileira de Agricultura Irrigada, 14(3), 4071-4085. https://doi.org/10.7127/rbai.v14n101167

Sales, J. M. J., Barreto, S. S., \& Aguiar Netto, A. O. (2018). Caracterização da bacia escola Jacaré-Curituba, em Poço Redondo-SE. In: Costa, P. R. S. M., \& Aguiar Netto, A. O. (Org.). Lugares, Potencialidades e Resistências: Terra e Povo no São Francisco. Aracaju: Criação Editora, 111-132.

Santos, H. G., Jacomine, P. K. T., Anjos, L. H. C., Oliveira, V. A., Oliveira, J. B., Coelho, M. R., Lumbreras, J. F., \& Cunha, T. J. F. (Ed.). (2006). Sistema brasileiro de classificação de solos. 2.ed. Rio de Janeiro: Embrapa Solos, 306p.

Santos, L. G. C. (2001). Diagnóstico dos Remanescentes de Mata Ciliar no Baixo São Francisco Sergipano afetado pela erosão marginal e a compreensão dos ribeirinhos sobre a degradação vegetal. Dissertação de Mestrado em desenvolvimento e meio ambiente. São Cristóvão: UFS, 105p.

Santos, S. J. S., \& Lucas, A. A. T. (2015). Diagnóstico da salinização ocorrente no solo do perímetro irrigado Jacaré - Curituba do território do alto sertão sergipano. In: Aguiar Netto, A. O. \& Santana, N. R. F. (Org.) Contexto Socioambiental das Águas do Rio São Francisco. São Cristóvão: EDUFS. 253-274.

Silva, V. P. R., Silva, M. T., \& Souza, E. P. (2016). Influence of land use change on sediment yield: a case study of the sub-middle of the São Francisco river basin. Engenharia Agrícola, 36 (6), 1005-1015. https://doi.org/10.1590/1809-4430-Eng.Agric.v36n6p1005-1015/2016

Silva, M. G. (2013). Modelagem ambiental na bacia hidrográfica do rio Poxim-Açu/SE e sus relações antrópicas. Tese de Doutorado em desenvolvimento e meio ambiente. São Cristóvão: UFS, 224p.

Silva V. P. R., Silva, M. T., Singh, V. P., Souza, E. P., Braga, C. C., Holanda, R. M., Almeida, R. S. R. Sousa, F. A. S., \& Braga, A. C. R. (2018a). Simulation of stream flow and hydrological response to land-cover changes in a tropical river basin. Catena, 162, 166-176. https://doi.org/10.1016/j.catena.2017.11.024

Silva, R. M., Dantas, J. C., Beltrão, J. D. A., \& Santos, C. A. (2018b). Hydrological simulation in a tropical humid basin in the Cerrado biome using the SWAT model. Hydrology Research, 49(3), 908-923. https://doi.org/10.2166/nh.2018.222 
Research, Society and Development, v. 11, n. 3, e48711326735, 2022

(CC BY 4.0) | ISSN 2525-3409 | DOI: http://dx.doi.org/10.33448/rsd-v11i3.26735

Shivhare, N., Dikshit, P. K. S., \& Dwivedi, S. B. (2018). A Comparison of SWAT Model Calibration Techniques for Hydrological Modeling in the Ganga River Watershed. Engineering, 4(5), 643-652. https://doi.org/10.1016/j.eng.2018.08.012

Souza, A. O., Carvalho, C. M., Gomes Filho, R. R., Garcia, C. A. B., Cerqueira, E. S. A., Valnir Júnior, M., Carvalho, L. L. S., Saraiva, K. R., \& Silva, A. F. (2021). Análise temporal e espacial das águas do perímetro irrigado Cotinguiba/Pindoba na região hidrográfica do baixo São Francisco Sergipano. Research, Society and Development, 10(2), e39210212403. https://doi.org/10.33448/rsd-v10i2.12403

Souza, R. M., Santos, I., \& Kobiyama, M. (2019). O modelo SWAT como ferramenta para a gestão de recursos hídricos: avaliação de vazões de outorga na bacia hidrográfica do Altíssimo Rio Negro. Anais... In: Simpósio Brasileiro de Recursos Hídricos, 18, Campo Grande: ABRHidro, 2019. https://www.abrhidro.org.br/SGCv3/publicacao.php?PUB=3\&ID=110\&SUMARIO=2047\&ST=o_modelo_swat_como_ferramenta_para_a_gestao_de_recurso s_hidricos_avaliacao_de_vazoes_de_outorga_na_bacia_hidrografica_do_altissimo_rio_negro

TAMU - Texas A\&M University. (2018a). Global Weather Data - Global Weather. https://globalweather.tamu.edu

TAMU - Texas A\&M University. (2018b). Soil \& Water Assessment Tool (SWAT) - Softwares. https://swat.tamu.edu/softwares

Tsakiris, G. (2015). The Status of the European Waters in 2015: a Review. Environmental Processes, 2, 543-557. https://doi.org/10.1007/s40710-015-0079-1

USGS, Earth Resources Observation and Science (EROS) Center Archive - U. S. (2018). Geological Survey (USGS) - Earth explorer. https://earthexplorer.usgs.gov.

Uniyal, B., Dietrich, J., Vasilakos, C., \& Tzorakic, O. (2017). Evaluation of SWAT simulated soil moisture at catchment scale by field measurements and Landsat derived indices. Agricultural Water Manage, 193, 55-70. https://doi.org/10.1016/j.agwat.2017.08.002

Van Griensven, A. V., Meixner, T., Grunwald, S., Bishop, T., Diluzio, M., \& Srinivasan, R. (2006). A global sensitivity analysis tool for the parameters of multivariable catchment models. Journal of hydrology, 324(1-4), 10-23. https://doi.org/10.1016/j.jhydrol.2005.09.008

Xavier, A. C., King, C. W., \& Scanlon, B. R. (2015). Daily gridded meteorological variablesin Brazil (1980-2013). International Journal of Climatology, 36(6), 2644-2659. https://doi.org/10.1002/joc. 4518

World Meters. (2019). World Meters Informations. https://www.worldometers.info/

WWAP - United Nations World Water Assessment Programme. (2017). The United Nations World Water Development Report 2017: Wastewater, the untapped resource. UNESCO, 198p.

WWAP - United Nations World Water Assessment Programme. (2018). The United Nations World Water Development Report 2018: Nature-based Solutions. UNESCO. $154 \mathrm{p}$. 